\title{
Working
}

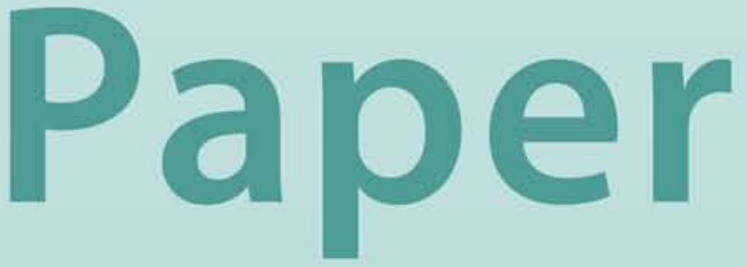




\section{The New Russian Budget System: A Critical Assessment and Future Reform Agenda}

Jack Diamond 


\title{
IMF Working Paper
}

Fiscal Affairs Department

\section{The New Russian Budget System: A Critical Assessment and Future Reform Agenda ${ }^{1}$}

\author{
Prepared by Jack Diamond \\ Authorized for distribution by Ke-young Chu
}

February 2002

\begin{abstract}
The views expressed in this Working Paper are those of the author(s) and do not necessarily represent those of the IMF or IMF policy. Working Papers describe research in progress by the author(s) and arc published to elicit comments and to further debate.
\end{abstract}

This paper documents the main elements of the new budget system established in the Russian Federation through its revised budget system law, or the Budget Code, of 2000. It critically examines the budget preparation, budget approval, and budget execution processes, as well as the financial management and planning procedures that underlie the Budget Code. Based on this analysis, recent developments are discussed and a future reform agenda is indicated.

JEL Classification Numbers:E6, D7, P2

Keywords: Budget System Law, budget reform, Russia

Author's E-Mail Address: jdiamond@imf.org

\footnotetext{
${ }^{1}$ A first draft of this paper was presented at a roundtable discussion held in the Finance Academy of the Ministry of Finance, Moscow, on May 17-19, 2000. The roundtable sessions formed the preparatory phase of the Russian Federal Treasury Training Program, organized by the Fiscal Affairs Department of the IMF. This revised paper, which has benefited from the helpful comments of Mr. Suhas Joshi, former FAD resident treasury advisor in Russia, Dale Chua, and other colleagues in FAD, forms part of the training materials in this ongoing training program.
} 
Contents

I. The Importance of a Budget System Law .........................................................

II. The Budget Preparation Process ...............................................................

III. The Budget Approval Process .......................................................................

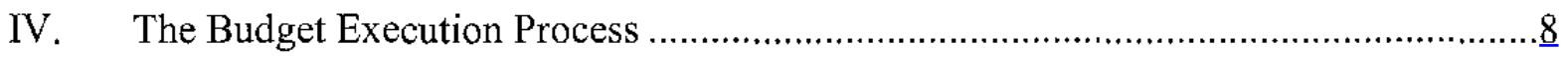

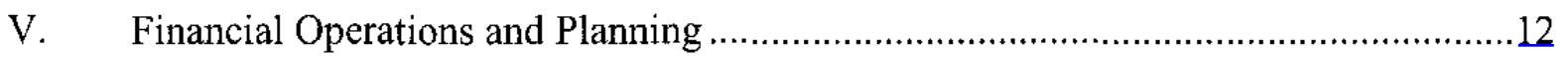

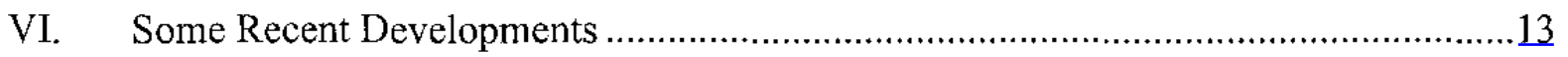

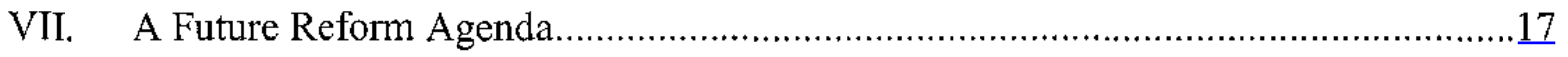

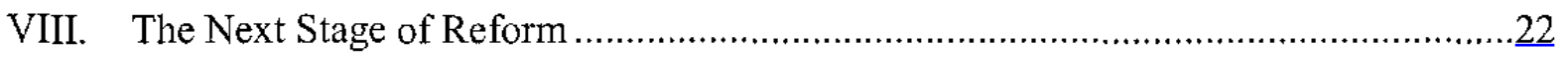

\section{Text Boxes}

1. Fiscal Rules Governing the Budget Process ....................................................

2. Key Elements of the Treasury System Supported by the Budget Code .........................

3. Powers to Adjust the Budget within the Fiscal Year .............................................11

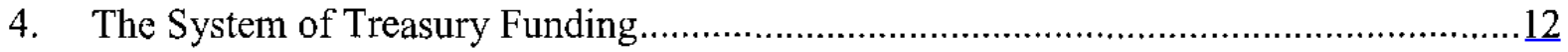

Annex

I. Russia: The Budget Formulation Process ......................................................24

II. Russia: The Budget Execution Process................................................................ 27

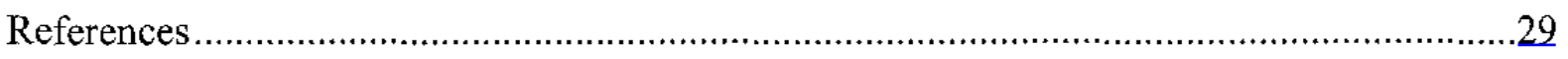




\section{The IMPORTANCE OF A BUdGeT SYSTEM LAW}

One of the major challenges faced by transitional cconomies has been to adjust institutions that were designed to function in a planning environment to function in an increasingly market-oriented environment. One of the most important of these institutional reforms has been the restructuring of the budget system. The latter should be interpreted quite widely to encompass the institutional framework as well as the administrative procedures that determine the means whereby resources are transferred to government, how the use of these resources is prioritized and directed to agreed policy objectives, and then subsequently managed, controlled, monitored, and reported on. Such systems must be defined in terms of a legal framework.

This legal framework can consist of the constitution, the organic budget law, and financial rules and regulations issued by the legislature or the ministry of finance. The approach can vary widely between countries. The United Kingdom and other common law countries rely on financial regulations, and established administrative and parliamentary practices to determine the budget system. Civil law countries, on the other hand, such as France and Germany, have codified their legal framework and have their budget system determined by an organic budget law. Transitional economies, lacking a suitable administrative and legal basis for establishing a market-oriented budget system, have found the latter approach more suitable. ${ }^{2}$

One cannot underestimate the importance of this legislation for the improved governance in transitional economies. A central purpose of such budget system laws is to provide a framework for accountability of a government's use of public funds. Three essential elements of accountability require to be covered in the law. The law should prescribe rules which govern the production of an annual fiscal plan, which relates government revenues and expenditures to the economic outlook, and secondly, an annual budget which articulates this fiscal plan and requires the formal approval of the legislature. The third element is the successful exccution of the plan in line with the annual budget authorized along with an annual set of public accounts presented to the legislature, which show actual spending compared with authorizations and reflect the overall financial position of the government. By assigning responsibility for each of these three tasks, and determining the information required to judge the success in accomplishing these tasks, a budget system law tries to ensure accountability.

Recently, Russia, like many of the economies in transition, has reformed its budget system by drastically changing the legal framework for budget management. ${ }^{3}$ This budget system

\footnotetext{
${ }^{2}$ See discussion in Chapter 2, Managing Public Expenditure-A Reference Book for Transition Countries (eds.).

${ }^{3}$ For a general review of this development see, W. Allan, "Toward a Framework for a Budget Law for Economies in Transition," IMF Working Paper 94/149.
} 
law, or Budget Code, first came into effect in FY 2000 and comprehensively covers all issues of fiscal management. This paper offers a critical appraisal of the new Russian budget system, critically examining the processes of budget preparation, budget approval, and budget execution prescribed in the law. In this review certain weaknesses are identified and recent attempts to address them are described. In conclusion, the paper offers an agenda for the further reform of the Russian budget system.

\section{The Budget Preparation Process}

The procedures for budget preparation, as laid out in the Budget Code, are described in Annex I. It is evident that the Budget Code describes a system, which has parallels in OECD countries. For example, the starting point is a macroeconomic framework; a top-down approach is described, with a budget to be formulated within clear macrofiscal rules (see Box 1).

\section{Box 1. Fiscal Rules Governing the Budget Process}

Art. 92 of the Budget Code stipulates:

- The federal budget fiscal deficit shall not exceed the total amount of budget investments and expenditures required to service the public debt.

- The budget deficit of a member territory of the federation may not exceed 5 percent of the revenues of the member, net of financial support of the federal budget.

- The deficit of a local budget may not exceed 3 percent of the budget revenues, excluding financial support from higher levels of government.

\section{A number of features of the budget preparation process should be noted:}

\section{The timetable for budget preparation}

The budget preparation process described in Annex I is evidently very detailed, with strict deadlines. This is partly due to the lengthy budget approval process (see below) and also to the Duma's envisaged input into budget preparation. However, the consequence is that budget preparation must commence very early in the preceding year. Thus the first detailed budget by functional classification is prepared by end-April, and by economic classification by early May, with the draft budget sent to the interagency commission, which resolves disputes in budget allocations, for approval by early June. While the Budget Code does envisage that cxpenditure and revenue (as well as financing) estimates in the budget are rooted in a macroeconomic framework, the need to adjust this framework in a sometimes rather unstable and volatile environment implies perhaps major adjustment of the framework on which the budget should be based throughout the preceding year. In any case, the Ministry of Finance's $(\mathrm{MoF})$ attempt at "top-down" aggregate control, based on affordability as assessed from a macroeconomic perspective, is further constrained, first, by the need to 
accommodate the Dumas's preferences in budget plans, and, second, by the two-step process by which budgets are prepared. The first step is to define aggregates in terms of functions, but then turn to the line ministries (LMs) to give bottom-up details in economic terms. This weakens the MoF's ability to constrain the line ministries, compared to total expenditure guidelines, or envelopes, normally sct as the first step in the budget preparation process encountered in most OECD countries.

\section{Institutional weakness in the budget preparation process}

The MoF as an institution remains relatively weak in tcrms of the basic skills of budget preparation. This is partly an information problem. Centrally, the MoF typically has very limited information about the expenditure base, a reflection of the old Soviet system that considered this primarily to be the responsibility of the line ministries. Information on outputs is not management-oriented and hence is largely irrelevant. The lack of relevant information at the center implies more power for the line ministries.

In part, the problem in budget preparation arises from the organizational structure of the MoF. The MoF has a central budget department, the Budget Policy Department (BPD), which is mainly a consolidator of the budgets of budget institutions. The line ministries, in preparing budget details, deal directly with "branch departments" of the MoF, which act as intermediaries with the BPD. In the past, some of these branch departments have seen their role as advancing the case for more resources for "their" particular LM or spending agency. Thus those involved in budget preparation in the MoF have tended to view their function as collating (or even endorsing) "bottom-up" budgets from line ministries and, therefore, have tended not to supervise, let alone, control the process. Perhaps, as a consequence, those departments in the MoF concerned with budget preparation have a limited capacity to challenge the affordability, desirability, and costing of individual expenditure policies.

\section{The quality of budget estimates is doubtful}

There are many reasons to suspect the realism of budget estimates. After several years of seeing their budget plans disrupted by cash rationing, budget institutions no longer have an incentive to take budget preparation as a serious exercise. Moreover, there are severe information constraints on producing good estimates. In the absence of up-to-date information on budget outturns, even in a preliminary form, those preparing budgets take the last budget as their starting point, not the latest or estimated outturn derived from the treasury system. Thus, one unrealistic budget becomes the starting point for the next. There is no established budget review function in the Duma, for example, in following up the external auditor's reports on the annual accounts that can really challenge the executive's budget. This, too, may have generated less careful attention to budget preparation procedures.

\section{A poor organizational budget classification has complicated the process}

Transparency in budget formulation has been disadvantaged in a highly decentralized systcm with too many spending units (SUs) supported by the budget, with loose supervision from an 
LM, and a cumbersome appropriations structure. A critical feature for budget preparation is the continued reliance on an imperfect functional classification-a mixture of the Sovietstyle planning branches and more internationally recognized functions-for the appropriation structure. An individual SU may receive resources from one or more main functional appropriation heads. A more transparent and accountable system, as in OECD countries, would base appropriation approval on individual SUs or line ministries. Also, the absence of an OECD-style program classification (not the quasi-functional system used under the old Soviet system) that can readily generate activity-based costing and analysis is a significant weakness. The number of SUs presents a problem in its own right, as discussed below.

\section{The Budget Approval Process}

The budget is approved in four readings:

- The first reading gives the broad framework of the federal budget, including macroeconomic forecasts, fiscal policy guidelines, and the principles governing interbudgetary relations, as well as external borrowing and other loans. Art. 198 of Budget Code allows 30 days to complete this from the date of submission.

- The second reading then presents the total expenditure of the first reading broken down by summary groups of the functional classification ("razdel"), including the level and distribution of transfers to the territories, and the total development budget. Art. 205.1 of the Budget Code allows 15 days to complete this alter completing the lirst reading.

- The third reading presents expenditure by razdel and "podrazdel" (sections of the razdel) and by line ministries. This reading includes details of federal "targeted" programs as well as the investment program, protected items, federal government guarantees, and details of external borrowing and loans. Art. 206.2 of the Budget Code allows 25 days for this after the passing of the second reading.

- The fourth reading approves the budget in general and is distributed by quarters. Art. 208.1 of the Budget Code allows 14 days for this stage.

Some features of this process deserve comment.

\section{Complexity of the process}

The approval process is unnecessarily complicated by, first, the number of stages, and second, the need to legislate quarlerly expenditure allocations. Most budget systems have two, or at most three, readings of budget legislation. The stages in the approval process should ideally be regarded as moving in increasingly detailed levels of the budget, from the macro framcwork, to broad functional classification to a detailed budget. However, the existing approval procedure is set up to complicate such a progression. At the first reading, the legislature has powers to submit the document to an arbitrating Conciliation Commission and return it to the government for revision. Even with approval of the first stage, 
amendments can be proposed by "entities with legislative initiative entitlement" to sclect Duma budget committees, and a conciliation commission can arbitrate agreements. Thus, in practice, successive stages risk reopening the fundamental budget strategy, leading to delay, ad hoc decisions, and potential deadlock.

\section{Unrealistic timetable}

The Budget Code seems to support the view that the legislature should play a major role not only in the formulation of budget stratcgy but also in its details. Although this is the United States' model, it should be noted that it is not the model in most OECD countries. While the formal approval procedure based on detailed budget scrutiny allows power for the Duma committees to fundamentally reformulate the budget if they so desire, the time limits allowed would not seem to permit this to be accomplished. Art. 211 of the Budget Code specifies that in case the approval process fails to deliver the budget by December 31, then the Duma may, in the first quarter of the year, pass a law financing first-quarter monthly expenditures equal to one-twelfth of the previous year's budget. However, the question remains whether the budget timetable is compatible with, and supports, the basic view of relative responsibilities between the legislature and the executive.

\section{Comprehensiveness of the budget}

From FY 2001, there is explicit treatment of extrabudgetary funds (EBFs) in the budget, although the large amount of off-budget activity of budget institutions is, in principle, incorporated in their budgets but not separately identified. While no statement of contingent liabilities, tax expenditures, or quasi-fiscal activities is published with the budget, a statement of federal government guarantees is presented.

\section{Transparency of government policies underlying budget allocations}

The approval process does not facilitate the normal prioritization of policies and their formulation into programs to be included in the government. This arises from two weaknesses in the Russian budget process, compared to OECD countries:

\section{- Lack of a clear medium-term budget framework}

The Russian authorities have appreciated the advantages of a medium-term budget framework, in the sense of a rolling forecast of fiscal aggregates for the budget year plus two forward years. While work has begun on such a framework, progress has been difficult owing to the unsettled economic environment. Its absence, however, implies that the medium-term implications of current budget decisions, and their sustainability, cannot be addressed. 
- Lack of a program basis to the budget

It can be doubted whether budget estimates are classified and presented in a way that facilitates policy analysis. The budget basically is presented and approved on broad functional groups (razdel), and their subgroups, various categories of expenditure. However, this "razdel" breakdown of the budget is far from ideal in identifying government policies and the programs that underlie these policies. The razdel classification reflects the more detailed functional budget classification as a mixture of the old sector breakdown, inherited from the previous planning environment, and the internationally accepted functional breakdown. The subfunction level ("podrazdel") should contain programs, but these are ill defined and often mixed with economic categories. As a consequence, it is difficult to work from policies to programs, subprograms, and the conscquent activities of each budget institution, as well as to differentiate new from old policy initiatives. In addition, a list of "targeted" programs is approved as an attachment to the budget, as is the breakdown of the functional expenditure by the totals allocated to each budget institution.

\section{The Budget Execution Process}

Annex II summarizes the various stages in budget execution. It must be remembered that the budget is executed through a rather decentralized budget system. Of the nearly 100 main budget institutions (line ministries and other important agencies with their own chapter in the budget), many supervise a large number of second-tier budget institutions, which, in turn, supervise third-tier institutions. All subordinate units report back directly to their supervising line ministry which, in turn, reports back to the federal MoF. Apart from this line of subordination, the federal treasury system operates a vast network throughout the federation, incorporating 89 regional offices, and under them, many branch offices-in total around 2,240 federal treasury offices cxist in the federation, employing around 50,000 employees. At the beginning of 2000, all but the Ministry of Defense (MOD) had its budget executed through this treasury network, and, as indicated below, there are plans to complete the treasury's coverage in the near future. As shown in Box 2, the Budget Code strongly supports the treasury system.

\section{A number of features of budget execution should be noted}

\section{Budget is prepared and approved on a functional basis, but executed on an agency/SU basis}

For the release of funds to implement the budget, the MoF indicates the broad aggregate funding levels to line ministries, and they, in turn, indicate the SU allocations to the treasury. The treasury then groups these SU allocations by their regional distribution (i.e., the region/branch treasury office that will handle the processing of payment orders). This dichotomy in information flows has contributed to poor information on budget executionreporting tends to be late and incomplete and lacks analytical meaning. 


\section{Box 2. Key Elements of the Treasury System Supported by the Budget Code}

1. Treasury's central role in budget execution

Art. 215: Specifically states that budgct execution will be through a treasury system and that the treasury shall act as cashier for all budget administrators and make payments from budgetary resources on their behalf.

2. The Treasury Single Account (TSA)

Art. 216: All reccipts and expenditures to be credited/debited to a single budget account.

Art. 236: Forbids the placement of budget resources in bank accounts.

Art. 244: The Federal Treasury (FT) is in charge of all accounts of the federal government.

3. The Treasury General Ledger (TGL)

Art. 240: Budget account to be based on a single Chart of Accounts (COA), organized by the budget execution authority, with approval of government.

Art. 256: Records of all transactions of federal government to be maintained in a general ledger, maintaincd on the basis of the approved COA.

\section{Reporting has become more difficult for budget institutions}

The treasury system is incomplete in its coverage, with some SUs still operating their own bank accounts, although most now have their payments made on their bchalf by the treasury. In the past, they produced the basic data, executed their budgets through the banking system, and had banking data available as a basis for budget execution reports. Now, since they execute their budgets through the treasury system, the treasury is the main source of this information. However, whereas responsibility for reporting on budget execution has changed, the FT, owing to administrative constraints and lack of comprehensive computerization, often finds it difficult to provide timely consolidated reports.

\section{The large number of budget users complicates budget execution}

Ambiguities have arisen regarding the definition of a budget organization, as well as the legal rights and obligations of such organizations. By FY 2000, there were around 17,000 budget recipients, including different types of organization. ${ }^{4}$ First, there are pure "SUs," subordinate to a ministry, funded out of the budgets of these ministries on the basis of their planned revenues and expenditures, entrusted with the management of government assets, and whose operational liabilities are recognized and assumed by government. Second, there are budget recipients which are SUs by their legal status, but which have large sources of off-budget funds. These are more autonomous units than the first category, but still predominantly carry out government policies. Third, there are units that are largely entreprencurial, but receive budget support for part of their operations, for example, to fund certain federal needs. This

\footnotetext{
${ }^{4}$ In early FY 2001, the MOF carried out a survey which indicated the following breakdown of budget recipients: Unitary companies and SOEs, 639 ; joint stock companies, 322, nonprofit organizations, 105. In addition to these 15,713 institutions, there were 205 others.
} 
support is specifically indicated in the budget. It should be noted that the number of budget recipients that receive appropriations as separate line items in the budget law is much smaller than the total number of SUs. The latter include subordinate budget organizations that receive their budget funding indirectly through their supervising budget institution. The total number of SUs is not known, but in FY 2000 it was estimated at 50,000 in the civilian part of government and at least 5,000 in the defense sector. In terms of budget execution procedures, these different units are treated equally.

\section{Budget institutions have legal rights that limit treasury control}

The Budget Code gives clearly defined powers to adjust the budget in line with revenue availability (Box 3). Art. 238 of the code gives institutions the right to total funding of approved commitment levels, which would seem to curtail the MoF's ability to cut back spending if available resources were less than planned. Moreover, the civil code Art. 120 gives "legal entity" status to budget institutions, protecting their right to operate bank accounts for "own-source" revenues and to enter contracts without MoF approval, which further curtails the MoF's ability to cutback spending. However, recent changes in the budget for FY 2001 have introduced three new clauses, which define the uses and restrict the powers of budget institutions to use "own-source" revenues. The FT is working to remove clauses of the Budget Code, such as Art. 163, which defines the rights of budget institutions to receive funding irrespective of budget cutbacks.

\section{Chart of accounts $(\mathrm{COA})$ and budget classification systems require to be restructured}

The CoA is the basis of the TGL and should be able to generate management reports on budget execution, as well as for other user needs. The reports so generated should be timely, accurate, and complete. From this perspective, the present approach to the treasury CoA has a number of weaknesses. The CoA used by budget institutions for their basic day-to-day accounting and submission of annual accounts, or so-called "analytical accounting," is supplemented by the treasury's "synthetic accounting."

The latter attempts to summarize and consolidatc the accounting of budget institutions through a CoA that does not fully reflect the budget classification and aggregates budget revenues and expenditures. Although substantial effort is devoted to the detailed analysis of borrowing (which again does not follow the budget pattern), below-the-line financing transactions tend not to be clearly distinguished from revenues and expenditures. Often the basis of accounting lacks consistency and clarity, combining an accrual basis for certain items and a cash basis for others. These synthetic accounts combine "flows" (i.e., payments and receipts) that are zero-balance accounts, and "stocks" (i.e., balances of liabilities and assets) with balances carried from one year to another. 


\section{Box 3. Powers to Adjust the Budget within the Fiscal Year as Contained in the Budget Code}

Art. 212: Government can propose changes to the budget whenever revenues exceed the approved budget target by more than 10 percent; requires parliamentary approval (elaborated in Art. 260).

Art. 213: Procedures to be employed in case of revenues falling below the approved budget target by more than 10 percent, requires parliamentary approval (elaborated in Art. 258).

Art. 224: Expenditures can be deferred without changes to budget outlays for up to three months provided such deferment does not exceed 10 percent of budget outlays for the quarter (elaborated in Art. 259).

Art. 229: If receipts are below approved budget target by no more than 5 percent, the $\mathrm{MoF}$ has discretion to introduce cuts in spending; if more than 5 percent but below 10 percent of approved budget outlays, the government has discretion to introduce expenditure cuts.

Art. 230: If parliamentary approval is delayed, following procedures in Art. 213, the MoF has the power to cut expenditures on a prorata basis until such approval is obtained.

Art. 231: The MoF has discretion to freeze expenditures, that is, reduce budget commitment limits, available to a budget institution if conditions on which the commitment was originally based are not met (e.g., if used for noneligible purposes).

Art. 234: The MoF has powers of reallocation (virement) between sections, subsections, earmarked items, and types of expenditure, within 10 percent of the budget allocations of chief budget administrators (ministries). (elaborated in Art. 261).

\section{Fiscal reporting is onerous and lacks management focus}

There are two channels of reporting: first, from the SUs, forwarded via their ministries or Regional Treasury Offices (RTOs), and sccond, from the SUs, via their ministries to the MoF branch departments and the BPD. Reports from the RTOs are received monthly and annually, and give details of both revenues and expenditures covering revenues and expenditures by classification codes indicated in the annual budget, total funds spent during the course of the month details of other noncash offsets, and details of the earmarked funds spent. Other reports received quarterly, give details of the funding of expenditures on a cash basis; they cover civilian ministries and the MOD.

There are some 24 separate reports required to be submitted by budget institutions to the MoF. Most of these reports are quarterly (typically only for the last 3 quarters of the year) or annual. Only one report is monthly, reporting on the execution of approved expenditure limits by type of spending, and is perhaps the most clearly relevant for budget management purposes. The extensive list of reports implies that the burden of SU reporting to the FT is very heavy. This flow of information is generally transmitted in paper form and not electronically, even in the Moscow region where most SUs are computcrized. The result is that reporting is an extremely costly effort in time and resources, not only for the SUs but also for the FT, which must key in and process this data, adding to the chance of crror and to 
delay in consolidation. The compliance orientation and the detail required means that the processing and consolidation of such data takes a considerable period of time.

\section{Financial Operations and Planning}

In the 1990 s, faced with a deficiency of resources to meet approved budget appropriations, the financial operations of the treasury assumed major importance. These are based on a monthly financing plan that is prepared each year based on the budget, and, in the absence of an approved budget, this has been based on the previous budget. Using the annual law on the federal budget, the BPD prepares limits on monthly expenditures. The procedure is detailed and cumbersome, and begins by determining the limits by razdel, or branch functions, and by podrazdel (subfunctions). When government has approved this functional distribution, this is then distributed to ministries. The ministries then determine what is the SU limit at the RTO level. The treasury is informed of the detailed limits and sends a block listing of such limits to each RTO for the SUs located in that area. The RTO in turn breaks down this block listing for each Local Training Office (LTO) for the SUs in its area. With the approved aggregate limits, the main department of the FT then begins to prepare a provisional cash-flow table identifying daily the taxes and other receipts expected and the priority expenditures that must be met.

The system of treasury funding is outlined in Box 4.

\section{Box 4. The System of Treasury Funding}

The government approves a monthly cash plan for each LM or higher-level budget administrators at the beginning of the year, which is drawn up by the BPD. It is understood that the LMs have the right to spend according to this cash plan.

The LMs prepare detailed payment registers to their subordinate SUs, which gives them authority to incur spending, consistent with these monthly financial limits.

The SUs submit payment orders to the LTOs and RTOs. If funds are available, and the requirement is within the authorized allocation then the FT office makes the payment.

If inadequate funds are available, priority is given to registered commitments and other priorities of the LMs. If these cannot be met, the SU must request its LM to approach the MoF in Moscow to make funds available.

In the central FT, the availability of cash is examined as well as projected inflows in the near future, and decision is made whether each payment can be made in full or in part. If payment is agreed, funds are sent to the relevant FT office to execute payment.

In the past, under severe fiscal stress, the monthly limits were set lower than the agreed budget, and often the cash available could not even meet the monthly financial limits. This implied that the FT was operating a daily cash-rationing system. However, with the improvement in the revenue position, at the end of FY 2000, although cxpenditures in certain areas exceeded the original budget allocations, there was no cash rationing, and indeed savings were transferred to the FY 2001 budget. 
Financial management in the $\mathrm{MoF}$ is relatively undeveloped. Forecasting is obviously difficult in the present environment. Forecasts are rather short term, generally only for a month ahead, relying primarily on past trends and levels attained in the immediate past, and concentrating on revenues. Cash management is admittedly constrained by external factors. The revenues are transferred from the BOR collection accounts to the operational FT accounts every five days. This lag implies that substantial cash balances are unavailable to the FT on a regular basis. Owing to the lack of development of the banking system, the FT finds it difficult to operate zero-balance accounts. As a consequence the FT leaves substantial cash balances on account at the RTOs to cover expenditures in the regions.

Other financial management operations, such as debt management, are outside the FT's mandate. Debt management is somewhat fragmented. The Securities and Financial Markets Department in the MoF makes the decisions, gives the treasury projections of debt service in advance of the financial ycar (as well as short-term projections), and records all such transactions, although the payments are executed by the treasury. For external debt, the Foreign Credits and Extcrnal Debt Department makes the decisions, negotiates the loan, and keeps records. The FT relies on the BOR for supervision of all subsequent cash flows, but they monitor the deposit of all receipts to the government account.

Some features of present financial planning arrangements should be noted. First, there is tendency to degenerate from financial planning into cash rationing. It is not difficult to appreciate that, in the recent past, problems of revenue shortfall, coupled with difficulties in projecting future revenue and expenditure developments, have made financial planning very difficult. In such an environment, the present system of cash releases has transformed into rationing out limited resources as they came in, according to strict administrative rules determined by political priority. Second, the relationship with the BOR has not been smooth. According to the BOR law, the BOR is supposed to maintain all the accounts for "the budget" and handle all budgetary payments. However, there is nothing in the law or supporting regulations that mentions the treasury or even the MoF. As a consequence, the FT/MoF have no special client status at the BOR and little influence in the way payments are made or classified. For example, the classification system of the BOR used for the payment orders of budgetary accounts is based on the old Sovict classification, with revenue classifications that now lack relevance.

\section{SOME RECENT DEVELOPMENTS}

The Budget Code is in its infancy, it will require some years before it can be implemented in its entirety. At the same time, the adoption of the Budget Code in FY 2000 made the future strategy for reforming present budget practices much clearer. The following review of most rccent initiatives indicates the direction of this reform strategy. It also reveals that to date reform initiatives have focused far more on improving budget execution processes, to the neglect of the other phases of the budget process, and have focused on strengthening compliance and meeting stabilization needs. 


\section{Resolving the arrears problem}

In the past, arrears have arisen from a number of sources: (i) fiscal indiscipline in powerful ministries, entering into commitments that exceed their approved budget allocations;

(ii) commitments made within budget allocations but below commitment levels set by the BPD; and (iii) commitments made within BPD limits but without treasury cash backing. Idcally, the approach to avoiding new arrears should be multifaceted: arrears arising from the first two sources may at least partly be addressed by more realistic budgeting, and arrears arising from failure to provide sufficient resources to meet commitments can be addressed by better financial planning. These ultimate solutions have not been fully implemented. However, as a first step, the need has been recognized for a system for monitoring, and then controlling, the commitments that are being made. Recognizing that it is not possible to control spending without controlling commitments has led to first registering commitments (concentrating first on a narrow band of contracts and then widening the coverage), with the presumption that the information will be eventually used to control commitments, so that payment orders can only be processed against registered commitments. By order no. 806 dated July 15, 1999, a system for recording commitments at the treasury was introduced for several ministries for selected spending codes. ${ }^{5}$

This is a significant first step toward building a database of commitment records. Over a period of time, if registration is implemented diligently, it may be hoped that the supplicrs will become aware that the FT will not meet payments in excess of the commitments and will become reluctant to supply those SUs, which are unable to ensurc the FT's stamp of approval on their contract. However, in implementing this reform a number of problems have become apparent.

\section{Addressing problems in controlling commitments}

At present, the responsibility for undertaking commitments is not clear. As indicated previously, the relation between a ministry and its subordinate unit is defined by the Civil Code Art. 120, which defines a subordinate institution generally as "an organization established by an owner to undertake social tasks in the social sphere financed by the owner according to a budget" where, most significantly, "the owner bears responsibility for all liabilities arising from this organization." Significantly, this legal problem implies that the FT cannot control the liability, rather it can only record it.

At the same time, commitments are often ill defined within the budget. It is unclear whether the federal budget represents a complete list of commitments. At present, the liabilities of the government often arise from entitlements from other lcgislation. In Russia, such entitlements

\footnotetext{
5 Namely, 110721, heating and technological necessities; 110722, consumption of natural gas; 110723 consumption of fuel for boilers; 110730 electric power; and 110740 water supplies to premises and facilities.
} 
are prolific, covering almost all spheres of life. There is some agreement that the quantification of these entitlements is difficult, and any attempt to limit these provisions is not easy. Another complication is that the Budget Code (Art. 238) appears to recognize that all appropriations can be committed and that a budget institution has the right to commit up to the tolal approved for it, regardless of resource availability.

The approach to registering and controlling commitments presently has a strong compliance orientation. However, such information should be an important input in budget management, both to budget preparation and setting commitment limits, as well as to financial planning. This cannot be taken lightly. In approving a commitment, the treasury is making an implicit guarantee of funds available to meet that commitment in the future. In turn, this requires strengthening its ability to track payment orders against contracts and improving cash management/financial planning. Both require improving the information base on commitments, which fundamentally will require the registering of commitments to be a component of the accounting system. Part of the problem is that the commitments undertaken by SUs are covered by off-budget resources, making it difficult to determine accurately the extent to which expenditures are uncovered because the FT has no verifiable information on the level of off-budget receipts. Recognizing this problem has led to measures to gain control of these "off-budget" resources.

\section{Integrating off-budget resources in the budget}

The off-budget activities of budget institutions expanded as pressures in the 1990s on their regular budgets have increased. These off-budget resources of budget institutions arise from many sources-entrepreneurial activity, grants, licenses, fees and charges, rent and interest income, etc. It is also possible for budget institutions to hold foreign exchange accounts arising from carnings overseas. The right to receive such compensation and undertake such activities is usually granted through various laws. For example, the law on education allows educational institutions to have accounts in banks to deposit these receipts. In 1999, it was estimated that these own-resource accounts were equivalent to 15-22 percent of total budget expenditure, although there is as yet little solid data in this area. So substantial and important are these activities that it is difficult to separate them from their statutory role, thus generating great possibilities for cross-subsidization and misuse of public funds. Although this problem appears to be larger and growing at the lower levels of government, attempts are under way to integrate these activities into the budget at the federal level.

The Budget Code is explicit in prohibiting off-budget accounts-such revenues and their related expenditures should form a regular part of a budget institution's plan of revenues and expenditures, and any surplus balances arising from such activity should be transferred to accounts in the FT (Art. 254.4). The code does allow an exception to this in the case where funding is below budget limits (Art. 254.6). However, when the federal law of the Budget Code was passed, it exempted budget institutions in the health, cultural, science, and education ficlds, thereby preserving existing laws. This, combined with the fact that the MOD organizations are also allowed to maintain off-budget revenue sources, means that a major part of "own source revenues" were exempted from the Budget Code provision. 
In the FY 2001 budget, three articles were added that strengthened the position of the FT in ensuring that: (i) off-budget revenues are fully registered (including from SUs in the areas of health, science, culture, and education); (ii) deposited in FT accounts; and (iii) allowing the FT to refuse payment for unregistered contracts even if partly funded from own-source revenues. ${ }^{6}$

\section{Expanding the coverage of the federal treasury system}

The extension of FT operations is being attempted in a number of areas that remain outside its control - the MOD, EBFs, and local budgets. The largest exception to the FT's coverage is the MOD. The Russian defense establishment operates as an enclave that is independent of the rest of the budget and normal budget practicc. This is manifested in many ways: the MOD has a separate budget classification and a corresponding different accounting system; treatment of social security payments on salaries is covered separately under the federal budget on behalf of the MOD; a large number of social SUs exist under the defense umbrella, paralleling and even overlapping other parts of the budget; and a number of military-related agencies have become semi-autonomous or "civilian" and placed off budget (e.g., Federal Defense Road Building Directorate).

In 1998, the MOD and the FT began two pilot projects in the Privolzhski military (Samara) region and the Baltic fleet, whereby the FT processed MOD payment orders. The lessons learned from these pilot projects indicated the large number of transactions, which could result from the inclusion of the MOD in the FT system, possibly ovcrextending the FT's present processing capacity. The present plan is to transfer the MOD to the FT in phases. The first, starting January 1, 2000, has already resulted in the Main Military Budget Department (MMBD) of the MOD opening an account in the central FT from which budget appropriations are allotted to lower-level units. The MMBD has also opened an account for centralized procurement in the RTO of the City of Moscow. Also, from July 1, 2000, the progressive transfer of the second-level units of the MOD to the FT for processing payment orders was completed. Thus, it is estimated that, by end-FY 2000, the FT operations covered about 60 percent of MOD expenditures.

By end-FY 1999, there were five major funds at the federal level - the Pension Fund, the Social Insurance Fund, the Fund for Medical Insurance, the Employment Fund, and the Road Fund. By Art. 7 of the FY 2001 budget, most EBFs were eliminated. The new CoA includes new heads of accounts for the three main EBFs - the Pension Fund, the Social Insurance Fund, and the Compulsory Medical Insurance Fund. Although technically inside the budget and under the FT, these funds have in the past used their own classification system and have

\footnotetext{
${ }^{6}$ Art. 21 specifies that revenues from off-budget activities must be fully registered with the FT (although it allows them to be used for the SU's own activities); Art. 111 states that the FT will not pay for unregistered contracts; and Art. 114 states that off-budget funds must be deposited in the accounts opened with the FT for that purposc.
} 
followed their own accounting rules. This implies that the true integration of these funds will take some time to be technically consistent with the treasury's ledger system.

At end-1999, the FT covered local budgets, of which 3,239 are serviced for revenues (either entirely or for part of revenues), and 413 for expenditures in specified categories. Apart from receiving lower-level revenues, the FT is responsible for the sharing of "regulated taxes." To execute the federal budget and the lower-level budgets, the FT must operate with six basic accounts, which are opened throughout the system, implying significantly over 2000 accounts for the FT alone. In addition, because regional and local governments are not integrated into the FT system, additional sets of control accounts at commercial banks are held on regional and local government accounts. These vast numbers of accounts hold significant balances and are difficult to manage.

In theory, lower-level governments enter the FT only on a voluntary basis, although in practice there is a current trend in government policy to extend more central control over the regions and hence greater pressure for them to enter the system. At the same time, suppliers (especially of utility bills) have insisted that the local government enter the treasury system before they sign contracts. The recent need of local governments to conform to the Budget Code, and the imposition of a common classification system, have meant that local governments have turned to the FT to do this for them. There are indications, therefore, that the FT will most likely have to expand its operations in respect to regional and local governments. Processing revenues may not be too difficult, but processing lower-level expenditures is likely to prove problematic, even though the FY 2000 budget has increased FT responsibilities. At present, while there are around 50,000 SUs in the FT system (excluding the MOD), it is estimated that at the local level there could be as many as 120,000 units.

\section{VII, A FUTURe Reform AGENDA}

Clearly, the Russian authorities have taken significant steps in recent years toward establishing a transparent fiscal management system, and the new Budget Code provides the overall legal framework in which to further develop such a system. From the perspective of future budget system reform, a two-stage strategy is perhaps in order. In the first stage, the budget process should be improved by introducing more transparent, internationally accepted standards, both in budget preparation and execution, for all government operations. In the second stage, there should be a move away from the present high degree of centralization in budget management toward a more decentralized approach in giving budget managers more scope to manage within strict accountability arrangements. In this stage, once compliance and stabilization controls are in place, the priority will be to improve the efficiency and effectiveness of government operations.

\section{Measures to improve transparency in budget preparation}

Many of the problems in preparing a realistic budget arise from the deficiencies of the prior stage within the budget cycle at which stratcgic options for the budget are clearly defined and 
reviewed, and binding decisions are made on overall budget strategy. Several factors contribute to the ineffectiveness of this stage:

- Lack of clarity in the respective roles of the executive and the legislature in budget formulation. The Budget Code makes provision for fundamental remaking of the budget by the legislature, yet the latter lacks either the technical support or the necessary time within the budget cycle to undertake this role.

- The process of budget formulation is relativcly centralized, with central agencies playing a relatively direct role in determination of allocations, including the use of centrally fixed expenditure norms.

- The substantial deviations between budgeted and actual expcnditure levels give little incentive for budget agencies to invest time and effort in realistic costing of policy options and preparing budget projections.

- At no stage in the process is there a transparent statement of budget strategy linking proposed policics, objectives, and broad budget allocations in a comprehensive manner (preferably more than a year ahead) that would facilitate clear decisions on what can and cannot be financed.

Again, these factors reflect the failure to review the strategic role of the government, and the fundamental problem of the lack of clear expenditure policies underlying budget allocations. As a result, the present basis for budget cstimates is not transparent, and does not ensure the connection between budget authorization and the real obligations of the government. A better definition of the expenditure estimates is required, for instance, by the BPD fully including registered commitments when formulating budgets. Transparency is further obscured by the budget being prepared and approved on a functional basis and largely executed on an agency or SU basis. This has contributed to the fact that most of the information produced by the budget process is late, incomplete, and lacks analytical meaning.

A two-part strategy seems feasible. First, for preparing the budget standards for revenue and expenditure estimates in the budget require to be developed modeled on international practices. These standards would be based on a clear definition of existing policy expenditure commitments and a methodology to ensure that ongoing costs of government services are fully estimated and realistically related to the macroeconomic framework. For this purpose, a manual on modern costing methods would prove useful.

Second, political approval of the budget should be improved by reducing the number of main budget units and SUs to encourage internal priority setting; presenting the budget for approval on a ministry/SU and program basis rather than the functional/ministry basis at present; on the same basis, developing a system of monthly and quartcrly reports aimed at performance review and supporting analysis of the current year's budget; and presenting estimates of tax expenditures with the budget document. 


\section{Measures to improve transparency in budget execution}

\section{Making the government payroll more transparent}

Government employment, and hence the payroll, is one area which lacks a coherent strategy, hence undermining sound budgeting. The government has acknowledged the need for reducing employment levels and improving public employee compensation. However, there is no real definitive data on the government's payroll. In addition, the wage bill is distorted by the provision of a wide range of benefits in kind-free apartments, medical clinic privileges, personal cars, subsidized meals, spa and resort services, etc.

Although these practices raise important issues of transparency, there appears to be little interest in the $\mathrm{MoF}$ in taking initiatives in this arca. As a result of the unreliable banking network, virtually all government employees are paid in cash on the basis of information submitted by a decentralized payroll unit in the line ministry. This essentially manual system is inefficient and vulnerable to fraud, and does not provide information to the MoF. Payment of salaries and wages constitutes over 23 percent of the government's noninterest expenditure in the 2000 budget. If the payroll is not computerized, control over such a large component of government expenditure will remain ineffective. A possible strategy would be to develop a standardized software package for payroll preparation, using the Social Fund Number as common identifier for payroll purposes. Develop a standard manual on payroll preparation for all budget institutions.

\section{Improving the accounting and classification of government operations}

For effective public expenditure management, the accounting system must be reorganized to serve as a timely provider of management information on budget execution. The CoA is the backbone of the accounting system. If it is not structured to capture the transactions in full budget classification format, then the FT will continue to have to rely on the reports of the SUs to monitor actual budget execution. In the past, this has been slow and unreliable, and since they cannot be independently verified, their completeness or accuracy is suspect. A major reform of the accounting system in the Russian Federation involves changing over from the present decentralized system to a centralized system.

In the latter system, the information will flow from the FT to the budget users, tax authorities, etc., and not vice versa, as at present. The government's transactions will be captured according to the Budget Code, only once, then entered automatically in the CoA by the computer software, avoiding the necessity of recompiling the data for reporting on budget cxccution. Of course, budget institutions will have to do their own detailed accounting operations - the keeping of detailed inventory for assets purchased and disposed of (e.g., for control and fiduciary purposes) and records for nonfinancial data (for management purposes to construct physical work-rate indicators, etc).

The treasury development project, presently being implemented with the financial assistance of the World Bank, will establish such a centralized accounting system, based on a CoA 
meeting international standards. This will require modifications to the present CoA, which presently does not fully reflect the budget classifications. The structure of the CoA aims to satisfy the needs of budget users in complying with detailed accounting regulations in producing their year-end accounting reports, and accordingly seems to treat accounting and fiscal reporting as two independent functions and are not interrelated.

\section{Complete the development of the treasury system}

A major step in the development of the treasury system was taken with the approval of a federal treasury development program by government resolution (no. 677) of June 23, 1999. The objectives of this program are to: implement a TSA in the BOR; centralize all government operations in the FT accounts; ensure the implementation of a uniform accounting and reporting system based on a single accounting and budget classification; develop, implement, and facilitate an integrated treasury computer/communication system interfaced with the BOR settlement network. Apart from the establishment of a network of regional and local FT offices, the three other pillars of a fully operational treasury system are only partially established: a general ledger accounting system (GLS), a TSA, which consolidates govcrnment cash resources, and a system of integrated financial management which minimizes the cost of government financing and guides the speed of budget exccution. ${ }^{7}$

Accordingly, the overall development of the FT's capacity should be encouraged, and, to this end, the authorities have developed a longer-term trcasury system modernization project, with World Bank loan funding. In the interim, it will be important to establish the fundamentals of FT operations, which will focus on three main elements, touched on previously. First, complete the development of a GLS (operated by the FT and integrating the accounting carried out in SUs) that will record all stages of expenditure, from appropriation, commitment, verification, and payment. Implementation will depend on computerization of FT and development of the interim system. Second, create a full TSA. Complete the coverage of the treasury system, by inclusion of all security ministries, and the off-budget activities of budget institutions, closing the associated accounts and transferring them to ledger accounts in the treasury. Third, develop a system of reports, to support a financial planning capacity that will construct rolling three monthly cash-flow forecasts, to guide the commitment limits of SUs and to adjust borrowing in line with cash flow requirements (see above). These developments will only prove effective if there is a concurrent cffort to upgrade government financial management skills.

\footnotetext{
${ }^{7}$ A full explanation of this approach, and the experience of developing such systems in BRO countries, is contained in IMF Occasional Paper no. 198.
} 


\section{Development government financial management capacity}

The procedures for distribution of budget allocations, and for setting limits on spending of the ultimate users of budget resources, are fundamental to proper budget management and the avoidance of payment arrears. Allocations are determined by the approved budget for the main budget institutions, which in turn prepare quarterly breakdowns of these appropriations for each of their subordinate units. Following this initial allocation, there are two important subsequent stages: the incurring of commitments and actual cash payment to settle these commitments. The responsibility in this area is divided between the BPD and the FT.

The BPD sets the level of commitments, by quarterly allocation of the annual appropriations, which is carried out at the level of economic classification. It also sets cash-expenditure limits each month by aggregates to cach ministry. The FT checks and approves the line ministries' proposals for breaking down their aggregate cash limits into spending limits for their subordinate SUs. These limits, prepared by detailed economic classification, are based on cash-balance reports from the BOR received every five days.

There are three main problems with the present approach. First, there is no guarantee that the commitment levels set by the BPD can be covered in cash by the FT. If the latter monthly spending limits have been exhausted, payments have to be deferred, even if commitments have been made within the approved commitment limit. Rather than commitment limits being the binding constraint on spending, the present practice favors limits on-cash payments-in the past, the consequence has been a buildup in arrears. Second, the BPD, by setting the monthly financial limits by aggregates, causes additional problems to the FT when this is used as a method to limit expenditures below the levels authorized for commitments. The FT has to monitor budget execution by composition of expenditure (economically classified) and the shortfall in financing has to be distributed by the FT among the various items at the economic classification level-either arbitrarily or based on the SU's preferences. It is difficult, therefore, to make expenditure cuts according to broader government policy priorities. Third, the FT system of cash rationing, by setting spending limits every 5 days, prevents the line ministries and their SUs from longcr-term planning of their budget execution and undermines their capacity to meet payments already committed within the commitment limits.

To overcome these problems, it is important to change the point of expenditure control away from the final cash-payment stage to the commitment stage. The poor revenue performance in past years may have necessitated such extreme cash-rationing measures, but, with the improvement in the fiscal situation since FY 2000, it is important to move toward a system that will control expenditures at the commitment rather than at the cash stage. The FT's cash-management system should be replaced by the release of funds on a monthly basis to match the expected level of payments related to the commitment limits, so that ministries and their SUs are assured that cash resources would at least match the commitments. This approach calls for the introduction of financial planning based on budget execution plans from line ministries and the development of a cash-flow forecasting model within the FT, based on information (forecast collections for the remainder of the year) from the tax 
ministry, customs committee, external and internal debt management departments, and the department of international financial institutions, as well as the data on actual collections and cash expenditures received from the accounting system.

\section{Strengthen the external audit function}

To support a reform program in public expenditure management, it is essential to establish external checks on budget performance. In this regard, the external audit function is critical. International experience suggests that this function is most effective when the supreme audit institution has: genuine independence from the executive, with timely access to comprehensive budget execution data; reports to the legislature, but is able to pursue a systematic, independently determined program of audit, with separate budgetary provision for any ad hoc investigations required by the legislature; and, confines its role principally to ex post audit, without compromise from any parallel engagement in the activities of budget formulation and execution.

In Russia, the Chamber of Accounts has been hindered in carrying out this role owing to three main factors: (i) inadequate expenditure reporting and accounts preparation by the executive; (ii) diversion from a systematic work program by the intervention of ad hoc investigations requested by the legislature; and (iii) dilution of its core responsibilities for ex post audit by other tasks, such as advice on budget formulation, intervention in budget execution, and an enforcement role with respect to implementation of audit findings and penalties. A strategy to relieve these weaknesses could include:

- improved timeliness and comprehensiveness in reporting budget execution by the executive (dependent on reforms in coverage and operation of the FT described above);

- legislative amendment to clarify the role of the Chamber of Accounts, defining its responsibilities principally in terms of ex post audit; and

- with this refocused mandate, technically reinforce the Chamber of Accounts with more suitably qualified personnel, computerization, and a training program.

\section{TIIE NeXT Stage of REForm}

It is evident that in pursuit of compliance and stabilization objectives, the Russian budget system presently features a high degree of centralization and a complex set of budgetary restrictions. These taken together have diminished the allocative and operational efficiency of budget exccution with budget managers operating with little responsibility or incentive to deliver results. The next stage of budget system reform will involve a fundamental reoricntation of the budget system-as has already been evidenced in OECD countries-to provide greater inducement for managers to focus on possible improvements in allocative and opcrational cfficiency in service delivery. This reorientation will require substantial capacity building in skills, which are currently in short supply. The present highly centralized budget system discourages the development of financial and allocative skills in spending 
agencies. To encourage such skills will require a more decentralized budget management system and one which allows managers greater freedom to manage. The risk with such increased flexibility is that spending agencies might undermine aggregate fiscal stabilization objectives when revenue conditions deteriorate.

At this stage in the budget system development, it would be unwise to move precipitously to this stage of budget system reform. Until the budget system can ensure fiscal discipline, and compliance with the law, and can provide a higher level of certainty in the spending agencies' opcrating environment, such a move could prove counterproductive. Full application of the Budget Code, and the suggestions for its strengthening, will certainly do much to improve the budget system's ability to ensure compliance and stabilization objectives. Perhaps more important, however, seriously addressing the reform agenda previously outlined will allow the budget system to move to the next stage of its development. 


\section{RUSSIA: THE BUdGet FormLla'tion Process, FY 2000}

\begin{tabular}{|c|c|c|}
\hline Step & Action & Time $^{8}$ \\
\hline 1 & $\begin{array}{l}\text { MoF submits to the RF government revenue and expenditure targets by the functional } \\
\text { classifications for federal budget } 2000 \text {. }\end{array}$ & $\begin{array}{l}\text { Within } 2 \text { weeks of the date of approval by } \\
\text { the RF government of the contingency } \\
\text { scenario for the economy in the next } \\
\text { fiscal year proposed by the MOE. }\end{array}$ \\
\hline 2 & $\begin{array}{l}\text { Macroeconomic Policy Department submits to Budget Department key } \\
\text { macroeconomic targets for } 2000 \text { and for period until } 2002 \text {. }\end{array}$ & By May 31, 1999 \\
\hline 3 & $\begin{array}{l}\text { Budget Department advises other MoF departments. The cap on budget } 2000 \text { revenue } \\
\text { and deficit (broad detail). }\end{array}$ & $\begin{array}{l}\text { No later than } 3 \text { days after the date of } \\
\text { approval of the financial plan by } R F \\
\text { government. }\end{array}$ \\
\hline 4 & $\begin{array}{l}\text { Tax Policy Department and International Cooperation Department advise Budget } \\
\text { Department of changes proposed in tax lcgislation. }\end{array}$ & By April 5, 1999 \\
\hline 5 & $\begin{array}{l}\text { Domestic Public Debt Department, External Sovereign Debt Department, and IFIs } \\
\text { Department submit to Budget Department estimates of domestic and external sources } \\
\text { of funds and costs of dcbt scrvicing during 1999-2002. }\end{array}$ & By April 7, 1999 \\
\hline 6 & $\begin{array}{l}\text { External Sovercign Department, IFIs Departmcnt, and International Cooperation } \\
\text { Department advise Budget Department of estimated cost of international activities in } \\
1999-2002\end{array}$ & By April 7, 1999 \\
\hline 7 & $\begin{array}{l}\text { Deputy minister in charge of State Committee on Precious Metals advises Budget } \\
\text { Policy of estimated proceeds from sales of precious metals and gems and amount } \\
\text { required to replenish precious metals/gem stocks. }\end{array}$ & By April 7, 1999 \\
\hline 8 & $\begin{array}{l}\text { Treasury submits to Budget Department data on tax breaks provided and their } \\
\text { expiration dates, budget loans, and repayment dates. }\end{array}$ & By April 7, 1999 \\
\hline
\end{tabular}

\footnotetext{
${ }^{8}$ Following the MOF Order No. 68 of March 31, 1999.
} 


\section{Russia: The Budget Formulation Process, FY 2000}

\begin{tabular}{|c|c|c|}
\hline STEP & ACTION & TIME $^{9}$ \\
\hline 9 & $\begin{array}{l}\text { MoF departments submit to Budget Department revenue and expenditure forccasts } \\
\text { for } 1999-2002 \text {. }\end{array}$ & April 8, 1999. \\
\hline 10 & $\begin{array}{l}\text { Budget Department, Tax Policy Department, Domestic Public Debt Department, and } \\
\text { External Sovereign Debt Department submit proposals to Macroeconomic Policy } \\
\text { Dept. on the financial plan for 2000-2002. }\end{array}$ & April 12, 1999 \\
\hline 11 & $\begin{array}{l}\text { Treasury informs Budget Department on execution on } 1998 \text { federal and consolidated } \\
\text { budgets, and submits to Budget Department preliminary report on execution of } 1998 \\
\text { federal and consolidated budgets and I Qtr } 1999 \text { federal budget. }\end{array}$ & $\begin{array}{l}\text { By April 25, } 1999 \text { and July } 1,1999, \\
\text { respcctivcly. }\end{array}$ \\
\hline 12 & $\begin{array}{l}\text { Budget Department informs MoF Departments of cap on federal budget } 2000 \text { outlays } \\
\text { by the functional classifications; departments propose a breakdown of allocations for } \\
\text { line ministries by groups and subgroups of the functional classification. }\end{array}$ & $\begin{array}{l}\text { No later than } 3 \text { days after the date of } \\
\text { approval of the financial plan by RF } \\
\text { government (BPD) 28/04/99 (MOF } \\
\text { departments). }\end{array}$ \\
\hline 13 & $\begin{array}{l}\text { Budget Department consolidates proposals of MoF departments on fed budget } 2000 \\
\text { allocations for line ministries by groups and subgroups of the functional } \\
\text { classification. }\end{array}$ & April 29, 1999. \\
\hline 14 & $\begin{array}{l}\text { Budget Department advises line ministries of the cap on federal budget } 2000 \text { outlays } \\
\text { by groups and subgroups of the functional classification accounts, works out the } \\
\text { schedule of work of the Interagency Commission. }\end{array}$ & May 1, 1999. \\
\hline 15 & $\begin{array}{l}\text { Line ministries submit to Budget Department breakdown of federal budget } 2000 \\
\text { allocations by earmarked accounts, types of expenditure, and the economic } \\
\text { classification. }\end{array}$ & May 15,1999 \\
\hline
\end{tabular}

\footnotetext{
${ }^{9}$ Following the MOF Order No. 68 of March 31, 1999.
} 


\section{Russia: The Budget Formulation Process, FY 2000}

\begin{tabular}{|c|l|l|}
\hline Step & \multicolumn{1}{|c|}{ Action } & \multicolumn{1}{c|}{ Time $^{10}$} \\
\hline 16 & $\begin{array}{l}\text { Department of External Debt Management and IFIs Department provide to Central } \\
\text { Bank information on foreign borrowings and costs of foreign debts servicing. }\end{array}$ & $\begin{array}{l}\text { By May 1, 1999 (preliminary), } \\
\text { November 1, } 1999 \text { (final). }\end{array}$ \\
\hline 17 & $\begin{array}{l}\text { Budget Department prepares the draft federal budget 2000; a list of disputes } \\
\text { regarding proposed allocations to be reviewed at the Interagency Commission. }\end{array}$ & June 3,1999. \\
\hline 18 & The Interagency Commission reviews and reconciles federal budget 2000 proposals. & June 7-15, 1999. \\
\hline 19 & Budget Department submits to MoF Board the draft federal budget 2000. & July $9,1999$. \\
\hline
\end{tabular}

${ }^{10}$ Following the MOF Order No. 68 of March 31, 1999. 
Russia: The Budget EXecution Process, FY 2000

\begin{tabular}{|c|c|c|c|c|}
\hline Step & $\begin{array}{l}\text { Department } \\
\text { Ministry } \\
\text { Agency }\end{array}$ & Action & Authority & Time \\
\hline 1 & $\begin{array}{l}\text { Budget Policy } \\
\text { Department }\end{array}$ & $\begin{array}{l}\text { Advises line ministries of their annual appropriations and } \\
\text { quarterly apportionment by the functional classification. }\end{array}$ & $\begin{array}{l}\text { MoF Order no. } 37 \mathrm{n} \\
\text { of May } 17,1999\end{array}$ & \\
\hline 2 & Line ministry & $\begin{array}{l}\text { Line ministry advises its SUs of quarterly apportionment of budget } \\
\text { funds, consolidates returnable limits on expenditures, and submits } \\
\text { to MoF quarterly apportionment of its budget by the functional } \\
\text { and economic classifications. }\end{array}$ & $\begin{array}{l}\text { Art. } 217.2 \text { of the } \\
\text { Budget Code }\end{array}$ & $\begin{array}{l}\text { Within } 10 \text { days of the date } \\
\text { of approval of the budget. }\end{array}$ \\
\hline 3 & $\begin{array}{l}\text { Budget Policy } \\
\text { Department }\end{array}$ & $\begin{array}{l}\text { Prepares a consolidated quarterly apportionment of budget funds } \\
\text { by the departmental, functional, and economic classifications and } \\
\text { submits it to the treasury (for execution), the Assembly, and the } \\
\text { Chamber of Accounts. }\end{array}$ & $\begin{array}{l}\text { Art. } 217.3 \text { and } 217.4 \\
\text { of the Budget Code }\end{array}$ & $\begin{array}{l}\text { Within } 15 \text { days of the date } \\
\text { of approval of the budget. }\end{array}$ \\
\hline 4 & Treasury & $\begin{array}{l}\text { Treasury head office advises line ministries of their annual } \\
\text { appropriations (the advice per se does not allow a line ministry to } \\
\text { incur expenditures). }\end{array}$ & $\begin{array}{l}\text { Art. } 220 \text { of the } \\
\text { Budget Code }\end{array}$ & $\begin{array}{l}\text { Within } 10 \text { days of the date } \\
\text { of approval of the } \\
\text { consolidated quarterly } \\
\text { apportionment. }\end{array}$ \\
\hline 5 & Line ministry & $\begin{array}{l}\text { Spending unit finalizes the revenue and expenditure budget and } \\
\text { has it approved by administrator of budget funds/line ministry. }\end{array}$ & $\begin{array}{l}\text { Art. } 221 \text { of the } \\
\text { Budget Code }\end{array}$ & $\begin{array}{l}\text { Within } 15 \text { days of the date } \\
\text { of advice on annual } \\
\text { appropriations. }\end{array}$ \\
\hline 6 & Bank of Russia & $\begin{array}{l}\text { Tax and other receipts are credited to treasury accounts in BOR } \\
\text { branches. }\end{array}$ & & On a rolling basis. \\
\hline 7 & Treasury & $\begin{array}{l}\text { Treasury regional/local office receives an account statement from } \\
\text { BOR branch; splits shared taxes between subnational and national } \\
\text { (federal) budgets; advises Ministry of Taxes regional/Local office } \\
\text { of tax payments received. }\end{array}$ & & On a rolling basis. \\
\hline 8 & Bank of Russia & $\begin{array}{l}\text { Advises treasury head of fice of balance in all treasury receipt } \\
\text { accounts with the Bank. }\end{array}$ & & On a 5 -day basis. \\
\hline
\end{tabular}


Russia: The Budget Execution Process, FY 2000

\begin{tabular}{|c|c|c|c|c|}
\hline Step & $\begin{array}{l}\text { Department } \\
\text { Ministry } \\
\text { Agency }\end{array}$ & Action & Authority & Time \\
\hline 9 & $\begin{array}{l}\text { Budget Policy } \\
\text { Department }\end{array}$ & $\begin{array}{l}\text { Determines and advises line ministries of monthly limit on } \\
\text { commitment of budget funds by functional and economic } \\
\text { classifications. }\end{array}$ & $\begin{array}{l}\text { Art. } 223 \text { of the } \\
\text { Budget Code }\end{array}$ & $\begin{array}{l}\text { At least } 5 \text { days before the } \\
\text { beginning of the month. }\end{array}$ \\
\hline 10 & Line ministry & $\begin{array}{l}\text { Prepares and submits to the treasury head office a requisition for } \\
\text { allotment of budget funds. }\end{array}$ & & On a rolling basis. \\
\hline 11 & Treasury & $\begin{array}{l}\text { Treasury head office processes requisitions from line ministries } \\
\text { for allotment and advises treasury rcgional offices that in their turn } \\
\text { advise administrators/SUs of the availability of funds. }\end{array}$ & & On a rolling basis. \\
\hline 12 & Treasury & Regional/local treasury office records commitments of SUs. & $\begin{array}{l}\text { MOF Order no. } 55 n \\
\text { of August } 13,1999\end{array}$ & \\
\hline 13 & Line ministry & $\begin{array}{l}\text { Spending unit submits a request for payment (payment order) to } \\
\text { the treasury regional or local office where it has a nominal } \\
\text { account. }\end{array}$ & & On a rolling basis. \\
\hline 14 & Treasury & $\begin{array}{l}\text { Treasury regional or local office processes payment orders of SUs } \\
\text { and submits them to the regional/local branch of the BOR for } \\
\text { execution. }\end{array}$ & & On a rolling basis. \\
\hline 15 & Bank of Russia & $\begin{array}{l}\text { Makes payment and issues an account statement to regional or } \\
\text { local treasury office. }\end{array}$ & & On a rolling basis. \\
\hline 16 & $\begin{array}{l}\text { Trcasury, line } \\
\text { ministries }\end{array}$ & Prepare accounting reports. & & Monthly, quarterly. \\
\hline
\end{tabular}




\section{REFERENCES}

Allan, Bill, 1994, "Toward a Framework for a Budget Law for Economies in Transition," IMF Working Paper 94/149 (Washington: International Monetary Fund).

Allen, Richard, and Daniel Tommasi, eds., 2001, Managing Public Expenditure, $A$ Reference Bookfor Transition Countries (OECD).

Potter, Barry H., and Jack Diamond, 2000, Setting Up Treasuries in the Baltics, Russia, and Other Countries of the Former Soviet Union, IMF Occasional Paper No. 198, (Washington: International Monetary Fund). 